\title{
Discourse of Nrima Ing Pandum in Novel Langit Mendhung Sajroning Pangangen by Tulus Setiyadi
}

\author{
Angelin $^{1}$ and Turita Indah Setyani ${ }^{2}$ \\ \{angelin@ui.ac.id ${ }^{1}$, turita.indah@ui.ac.id ${ }^{2}$ \} \\ ${ }^{1,2}$ Javanese Study Program, Faculty of Humanities, Universitas Indonesia, Indonesia
}

\begin{abstract}
The Langit Mendhung Sajroning Pangangen (LMSP) novel one of the contains moral values about the acceptance of whatever God gives that are conceptually the inheritance of Javanese ancestors. In the Javanese culture, that attitude is known as nrima ing pandum which is almost the same as the sepi ing pamrih attitude 'unconditional' for the purpose of living of memayu hayuning bawana 'beautify the life of the universe'. Therefore, the nrima ing pandum attitudes is very important to be studied, since such attitudes have relevance in the present. This article aims to uncover the discourse of nrima ing pandum in the LMSP novel with uses the anthropological and Javanese religious perspective for the read of text in the Javanese anthroporeligio context. The result is reveals that the discourse of nrima ing pandum contained in the LMSP novel is described based on the three attitudes that make a person nrima ing pandum, namely rila, nrima, and patient as inseparable attitudes. The conclusion is proves that the value of Javanese culture, especially value of nrima ing pandum, still maintained by the supporting community and still very relevant to be used in everyday life and can be realized in the life of today's society.
\end{abstract}

Keywords: nrima ing pandum, moral value, local wisdom, Langit Mendhung Sajroning Pangangen Novel

\section{INTRODUCTION}

Nrima ing pandum does not mean just surrender at the fate that exists, but has the meaning of receiving with sincerity and always trying to do something the best that can be done. Nrima means that people who are in a state of disappointment and difficulty reacted rationally, with no collapse and also with no anger [1][2]. Nrima also means not wanting something possessed by others, and not jealous of the happiness of others, therefore nrima can be said to be a thankful person to God [3]. The nrima attitude taught in Javanese culture makes one grateful for what is owned and not proud of himself.

The attitude of nrima ing pandum in Javanese culture has relevance to other concepts, sepi ing pamrih and memayu hayuning bawana. The word memayu comes from the word ayu with prefix. In the Javanese Baoesastra dictionary, ayu has the meaning of 'good', 'congratulations', 'beautiful' [1], whereas prefix is defined as a verb meaning 'do', 'make' or 'to'. Therefore, the 
word concluded has the meaning of 'beautify' or 'beautify'. Furthermore, the word hayuning also derived from the word ayu who got additional pronouns belonging at the end of the sentence ie -ning 'its'. Thus, the word hayuning concludes to mean 'beautiful' or 'safe'. Furthermore, the word bawana in Baoesastra Javanese dictionary has the meaning of 'home', 'residence', 'universe' [3].

In the Javanese religious community, there are concepts that can help people in their daily life. The most basic concept is the concept of kosmos, kosmos is a balanced system. There are other Javanese religious concepts that can maintain the balance of the kosmos. The first concept is sangkan paraning dumadi, then the concept of manunggaling kawula gusti, continues to kasampurnaning dumadi concept, and leads to the concept of memayu hayuning bawana. These concepts lead to human attitudes as embodiments of the application of these concepts. One of these attitudes is nrima ing pandum. The concept of sepi ing pamrih is the attitude of a person who will not be anxious and concerned about himself, against the lusts of the world, the sense of wanting to have everything ing the world, even disappeared [1]. The concept is in line with the concept of nrima ing pandum. Someone applying the concept of nrima ing pandum is definitely applying the concept of sepi ing pamrih, because sepi ing pamrih is the first step to go to nrima ing pandum. It is clear that to be able to reach nrima ing pandum must have three inseparable attitudes, namely 'willing/sincere', nrima 'acceptance', and patience (tolerance) [4].

This paper examines the discourse of nrima ing pandum contained in the LMSP novel. The purpose of the study is to reveal how the attitude of nrima ing pandum is presented in the LMSP novel. Assessment of nrima ing pandum attitudes is carried out using the anthroporeligio perspective contained in the novel, in order for the embodiment to be completely dissolved. Religious studies through anthropological review can be interpreted as an effort to understand religion by looking at the form of religious practices (actions, behaviors) that grow and develop in society [5]. Religious elements can be explained through the approach of anthropology and other social sciences.

Discourse is a series of words or a series of speech acts that reveal a thing that is presented regularly, systematically, in a coherent whole, formed by segmental elements and nonsegmental elements of language [6]. Johnston argues that to analyze a discourse requires the following six things: the world, the language, the participants, the prior discourse, the media (medium), and the purpose [7]. While anthroporeligio literature is a perspective that examines a literary work based on anthropology and religious studies as the basis for discussion.

One of the previous research which has similar discussion, that is in the form of thesis FIB UI (Javanese Studies) entitled "Character, Theme, and Message in novel Sawise Langit Katon Biru (SLKB)" by Hemas Bunga Kesuma Ningdya. The research in this study uses a structural approach with the objectives of the study: (a) describes the description of the characters and the characterization of novel SLKB; (b) conveying the theme of the story and expressing the message contained in the SLKB novel. The message conveyed as the conclusion of the research is about the sepi ing pamrih actions of the main character who implicitly gives lessons to other characters. Differences of previous research with this research lies in how to apply method and focus of discussion. previous research defines the elements of structure in review it to obtain the theme and the message contained in SLKB novel. The study seeks to elaborate the discourse on nrima ing pandum in a modern Javanese novel, Langit Mendhung Sajroning Pangangen LMSP with anthroporeligio literary perspectives.

Langit Mendhung Sajroning Pangangen novel (hereinafter referred to as LMSP) novel used as disccuss data is a new novel by Tulus Setiyadi. LMSP published by Pustaka Ilalang in 2017 in Lamongan. The novel consists of 11 chapters, telling about the life of adolescents in the region of Java in this day. The novel contains several moral messages, either express or implicit 
in the story. These moral messages are very useful in human life today. One of the moral messages is that in helping others, a person should not expect rewards. In the context of Javanese culture such a thing is called sepi ing pamrih 'unconditional'. In addition, a person must accept whatever is given by God. In Javanese culture, accepting anything given by God is called nrima ing pandum. So, this article focuses on discourse of nrima ing pandum in the LMSP novel.

\section{METHOD}

The technique used in this research is literature study, collecting data to conduct theoretical studies on references and literature from various books relating to the culture, values, and norms that developed in the social situation under study. In this research the discourse of nrima ing pandum will be described through inter-firm conversation using descriptive analytic research method. Descriptive method of analysis is done by describing the facts which then followed by the analysis [8]. The steps taken in this research that is by determining the object of research first. Furthermore, degrading the data in the novel related to the discourse of nrima ing pandum and then analyzed the discourse of nrima ing pandum materialized in LMSP novel.

\section{RESULT AND DISCUSSIONS}

In this section, the summary of the discourse of nrima ing pandum is explained. There are three steps to take to realize nrima ing pandum, rila, nrima, and patient. In addition, the three steps will be explained too. Selain itu, perlu disandingkan pula uraikan tentang non-nrima untuk mempertegas perwujudan nrima ing pandum.

\subsection{Nrima Ing Pandum Attitude in Novel LMSP}

The nature of nrima in LMSP's novel is very much inherent with the depiction of the Narko figure. Narko is the only character who has such traits from the beginning to the end of the story, in the simplicity of his life Narko does not even hesitate to help others without expecting a reward. Narko can be a role model of the young generation of Javanese society today [9].

The actions done by Narko strongly indicate that he really wanted to help others who he thought needed his help. He also convinces the other person to believe that he will not do evil and harm the person. The act he did without thinking about negative things that might happen, because he did not know the person who will help [9]. Narko has a sense of compassion towards others who are experiencing difficulties even though he does not know the person. There was no suspicion at all in helping the stranger he had just met. He also dared to risk himself as a form of responsibility in helping others who he did not know [9]. Narko's attitude of nrima shows that in its application, the discourse of nrima ing pandum has a resemblance to the concept of sepi ing pamrih, rame ing gawe [9]. This merciful attitude is merely the result of sepi ing pamrih rather than the purpose in itself [10].

In living his daily life Narko portrayed never complained of his fate, he even always tried to do everything maximally but did not force in order to get the best results [9]. If a person still forces the will (wants to get the best) by doing various ways, then that person can certainly not understand the real Javanese lifestyle. Javanese people who have found consciousness through the concept of nrima ing pandum when in a difficult condition though will not feel burdened. The nrima nature can make the poorest people feel happy, because their happiness does not arise because of material objects [4].

The strong determination wrapped in the simplicity of the Narko figure continues to be revealed in the LMSP novel. In addition to a strong determination to always do good to others, 
Narko also has a strong determination to continue his education. The economic conditions did not stop Narko's desire to earn a Bachelor's degree [9].

The person who understands the whole concept of nrima ing pandum is a person who is not very concerned with worldly matters but does not mean to abandon all the things of the world, a good man is a human being with God, and with the order of society determined by God [10]. Narko accepts Nuning's circumstances because he already has true love. True love is a feeling that has not thought of reciprocity. Nuno's affection for Nuning became more and more intense, he was convinced that Nuning was the right partner for her. The physical limitations that Nuning was experiencing were not an excuse to leave Nuning [9].

Based on the analysis it is seen that a person who applied the attitude of rila is someone who sincerely gives what he has without asking for the slightest reward. The man who is rila will not be concerned about what he has given to others, he still asks others about what they need, assuming that he is ready to help others anytime and anywhere. Rila attitude based on rasa. It can be interpreted that someone who has a higher sense of sensitivity is someone who can be rila $[11]$.

The nrima attitude by Narko shows that a person with nrima attitude can always be grateful to God. People with nrima attitude also tend to forgive those who have done evil to themselves. Nrima attitude allows a person to live their life as it is but does not stop trying. The effort is also based on the intention of obtaining sustenance from God, there is no intention to pursue a worldly thing like wealth, pleasure, or position in this world [11]. Patient attitude describes a person who has a mixture of rila and nrima attitudes. A person who is patient will live his life calmly, will not complain if he is in trouble, even in difficult times he still prioritizing the safety of others. The ability to refrain from anger, disappointment, and anxiety is patience [11]. The patient man is able to grapple slowly with problems that he has and finds a way out of them.

\subsection{Non-Nrima Attitude}

Non-nrima or not nrima ing pandum is interpreted as not accepting what has been given [12]. The non-nrima actions in the LMSP novel are represented by the characters Panji and Nuning [9].

In the middle of the story, the two figures who had been told about his non-nrima attitude, Panji and Nuning, were told more deeply. Panji was an old friend of Narko, he and Narko were members in a literary community. At the beginning of his presence in the mid-story of LMSP novel, he explains that during this time he never had a relationship with Narko and other figures due to many problems to be solved, he admitted grateful that he can survive so far [9].

Panji has been struggling to solve his life problems, his gratitude shows that he is struggling with a heavy heart and lacks the belief that God will always help someone in solving life problems. Panji's character implicitly confirms his sister's statement, Yani, at the beginning of the story that since her mother died, Panji has often been hit by a problem that caused him to break the bond with his friends and doesn't know where they were. The next incident that is happenes revealing Panji's true nature is when he learns that someone has hurt his sister. Panji was very angry at that [9].

Panji character increasingly shows the true nature he had after knowing the disaster that happened to his sister. In fixing the problems of his life, ways of thinking and low self-control look less mature and not nrima. It is depicted from the event that he complained of his fate, he assumed that all this time his life was always overwritten by various problems. It is a form of regret for the life it undergoes, showing that one does not believe in God's miracles, and does not realize that God will always make way for those who will strive without imposing the will to get the best (using every means). Panji does not develop his feelings, he shows signs of lack 
of inner development [9]. A man who allows himself to be carried away by his human emotions or pamrih is immature.

Panji had stated that sometimes he can only accept and surrender to the situation without continuing to do business [9]. The statement is very contrary of the nature of nrima. If a person really has a nrima nature then he will never complain, that person will continue to try and believe that God loves all his creatures.

Panji states that he is better off leaving this world and will be at peace there, but then Mistiyani reminds him of his brother. Panji was immediately reminded of his sister who has been the only encouragement in continuing life [9].

At the end of the story, Panji felt very sad for Narko's death. He felt so lost and cursed himself that he should be the one who left this world. This still indicates that Panji is desperate to surrender with his life [9].

On the other hand, Nuning's character is also described as having non-nrima nature at the beginning of the story. It is related to the calamity that happened to her so that until now she cannot walk using both legs. In chapter four, Nuning returns to meet Narko after all this time. Embarrassment and lack of self-confidence were still enveloping Nuning at the time, she realized that the situation was different from the first, but on the other hand she missed her friends, especially Narko. The feeling of longing is a bit overwhelming the shame she had felt [9].

The beginning of Nuning's meeting with his friends, especially Narko, Nuning is still a bit self-confident, but over time, because of the support provided by her friends and family, she began to show her passion and aspirations of her life. Nuning describes that she still feels unworthy of meeting her friends, still not feeling sincere about her current situation [9]. This is confirmed by Suseno in his book Javanese Ethics that a sincere individual would be willing to let go of individuality itself and fit into the great alignment of the universe as prescribed [1].

In the next section, Narko also expressed his feelings, he said that he would apply for Nuning as soon as possible. Nuning responded with pleasure and was delighted to learn that there was a man who was willing to accept herself as she was [9]. Then Nuning again tested her fortitude in living life. The problem she faces is at its peak. Recently she regained her confidence thanks to the emergence of Narko and Narko's willingness to accept it as it is. Now his hope just disappeared. She also has no desire to go on with her life, she thinks that no man will ever accept herself as she is [9].

In chapter ten, Nuning, who from the beginning to the end of the story shows the change, has begun to show nrima attitude suddenly sad again and continue to condemn her fate due to the death of Narko. She still cannot let go of Narko even though she has been working on it [9]. After Narko's death, Panji and Nuning were able to adopt a more rila, nrima, and patient attitude in their lives. The change in the nature of the two characters is believed to be influenced by the notion that Narko has become one of those who inspires their lives. Feelings of happiness also increasingly affect the changes in the nature of Panji and Nuning [9].

The realization of the attitude nrima ing pandum to figures other than Narko, namely Panji and Nuning influenced by the attitude Narko during his life. This proves that the attitude of nrima ing pandum, besides beneficial in the life of the culprit, is also beneficial to the surrounding environment. The positive energy propagated by those who apply that attitude can inspire others to apply the concept as well, step by step. In addition, based on the analysis, it is known that the characters who do not apply the attitude of nrima ing pandum lead an anxious life. It is due to the frustration that continues to be present in their minds. The sadness of thinking about a future that is considered dark also makes them think that it is better for them to leave 
this world. Non-nrima attitude is not very good to be done in social life, because the negative energy will easily spread in an environment.

Nrima ing pandum is a receptive attitude to what has given by life. Philosophy of narimo ing pandum covers three psychological constructs, namely acceptance, patience, and gratitudeness [13]. The discourse of nrima ing pandum contained in the LMSP novel is described based on the three attitudes that make a person nrima ing pandum, namely rila, nrima, and patient. These three things are inseparable attitudes [14].

\section{CONCLUSION}

Based on the description and study of the discourse of nrima ing pandum, the attitude of nrima ing pandum is presented expressly or implicitly in LMSP's novel, the attitude is presented through the events experienced by the characters in their life. It can be seen that the attitude (when applied in everyday life) can lead someone who runs it to live a happy life. Although it has many problems, but can surpass it with a roomy heart. It is also known that the discourse of nrima ing pandum has a resemblance to the concept of sepi ing pamrih, which is both a path to a happy life, a harmonious life, harmonious and balanced, so as to achieve harmony of life in accordance with the purpose of the concept of memayu hayuning bawana. Therefore, the discourse of nrima ing pandum is still very relevant, so it is important to be studied and applied in everyday life. However, there is a need for special learning on religious concepts in Javanese culture that can be applied by the young generation in this era of globalization. Along with the influx of other cultures that are very influential on the development of the younger generation, Javanese society and other Indonesian society need to apply the values of local culture. Implementation of local cultural values as a national identity and a fortress of national and state identity.

Acknowledgement. This research is fully supported by Hibah Publikasi Internasional Terindeks untuk Tugas Akhir Mahasiswa 2018 funded by DRPM Universitas Indonesia No. 2012/UN2.R3.1/HKP.05.00/2018.

\section{REFERENCES}

[1] F. M. Suseno, Etika Jawa: Sebuah Analisa Falsafi Tentang Kebijaksanaan Hidup Jawa. Jakarta: Gramedia, 2003.

[2] S. Tartono, Pitutur Adi Luhur. Yogyakarta: Yayasan Pustaka Nusantara, 2009.

[3] B. Herusantoto, Simbolisme Jawa. Yogyakarta: Ombak, 2008.

[4] S. de Jong, Salah Satu Sikap Hidup Orang Jawa. Yogyakarta: Kanisius, 1976.

[5] F. U. Rosidah, Pendekatan Antropologi dalam Studi Agama. Surabaya: IAIN Sunan Ampel, 2011.

[6] S. Aminah, Analisis Wacana Pesan Moral dalam Novel Laskar Pelangi Karya Andrea Hirata. Jakarta: UIN Syarif HIdayatullah, 2008.

[7] B. Johnstone, "Discourse analysis and narrative," in The Handbook of Discourse Analysis. Blackwell Publishers, 2001.

[8] N. K. Ratna, Teori, Metode, dan Teknik Penelitian Sastra. Yogyakarta: Pustaka Pelajar, 2013.

[9] T. Setiyadi, Langit Mendhung Sajroning Pangangen. Lamongan: Pustaka Ilalang, 2017.

[10] J. A. Boon and N. Mulder, "Mysticism and Everyday Life in Contemporary Java: Cultural Persistence and Change.," J. Asian Stud., 2006. 
[11] T. Hardjoprakoso and T. Soemodihardjo, Sasangka Jati. Jakarta: Proyek Penerbitan \& Perpustakaan "PANGESTU," 1976.

[12] S. Hariwijaya, Kamus Idiom Jawa. Jakarta: Eska Media, 2004.

[13] R. Maharani, "Penerapan Falsafah Narimo ing Pandum dalam Pendekatan PersonCentered untuk Mengatasi Depresi Remaja. Prosiding Seminar Nasional Bimbingan dan Konseling," UNIPMA, vol. 2, no. 1, 2018.

[14] S.T. Widodo and K. Saddhono. "Petangan Tradition In Javanese Personal Naming Practice: An Ethnoliguistic Study." GEMA Online® J. of Lang. Stu. vol. 12 no. 4 pp 1165 1177, 2012 